(c) American Dairy Science Association, 2007.

\title{
Occurrence of Selenoprotein Enzyme Activities and mRNA in Bovine Mammary Tissue
}

\author{
K. Bruzelius, ${ }^{\star 1}$ T. Hoac, ${ }^{\star 1}$ R. Sundler, $\dagger$ G. Önning, ${ }^{*}$ and B. Åkesson ${ }^{\star} \ddagger^{2}$ \\ *Biomedical Nutrition, Faculty of Engineering LTH, Lund University, Lund, Sweden \\ †Department of Experimental Medical Sciences, Lund University, Lund, Sweden \\ $\ddagger$ Department of Clinical Nutrition, Lund University Hospital, Lund, Sweden
}

\section{ABSTRACT}

To elucidate the possible role of selenoproteins for milk formation and mammary gland physiology, the activities of selenoprotein enzymes and the expression of selenoprotein genes were studied in the bovine mammary gland. Messenger RNA was demonstrated for selenoprotein $\mathrm{P}$, thioredoxin reductase 1 , and for glutathione peroxidase (GPx) 1, 3, and 4. Significant differences in mRNA expression between the cows were seen for GPx 1 and GPx 3. The enzyme activity of glutathione peroxidase varied approximately 16 -fold among cows, and the activity of thioredoxin reductase and the concentration of soluble Se varied approximately 6-fold among cows. There were positive correlations between glutathione peroxidase activity, thioredoxin reductase activity, and soluble Se, the correlation between glutathione peroxidase activity and soluble Se being the strongest. Furthermore, selenoprotein $\mathrm{P}$ expression correlated with GPx 1 mRNA expression and with soluble Se. There was also a correlation between glutathione peroxidase activity and the mRNA expression of GPx 1. The general conclusion from the data was that the activity of glutathione peroxidase and thioredoxin reductase and the mRNA expression of selenoprotein $\mathrm{P}$ and GPx 1 and 3 were influenced by Se status, but the expression of GPx 4 and thioredoxin reductase 1 were not. These results indicate that the Se status in mammary tissue is an important regulator of selenoprotein activity and expression, but that other factors are also in operation.

Key words: mammary tissue, selenoprotein, glutathione peroxidase, thioredoxin reductase

\section{INTRODUCTION}

Selenium is an essential nutrient due to the actions of specific selenoproteins, which are involved in many

Received August 23, 2006.

Accepted October 2, 2006.

${ }^{1}$ These authors contributed equally to the study.

${ }^{2}$ Corresponding author: bjorn.akesson@kc.lu.se important life processes. Selenium is specifically incorporated as selenocysteine into selenoproteins, but it can also be incorporated in an unspecific manner in proteins as selenomethionine. Using bioinformatic methods, 25 selenoprotein genes have been found in the human genome (Kryukov et al., 2003). Some of these selenoproteins are enzymes, whereas the physiological functions of others are still unknown (Behne and Kyriakopoulos, 2001; Schweizer and Schomburg, 2005). In many tissues and organs the supply of Se is a major regulator of selenoprotein content, but it is also known that selenoproteins are regulated individually. Certain selenoproteins are prioritized when the Se supply is limited and change very little, whereas others, like cellular glutathione peroxidase 1 (GPx 1), are strongly influenced by the Se status. The regulation of selenoprotein metabolism in mammals is very complex, and numerous factors and systems are involved in the regulatory machinery (Behne et al., 1988; Müller et al., 2003).

Selenium deficiency or low Se status has been linked to various diseases in humans such as cancer diseases, cardiovascular diseases, and Keshan disease (Rayman, 2000; Beck et al., 2003). Breast cancer experimental studies have shown a connection between tumor development and Se deficiency (Ip et al., 1996; Unni et al., 2004), but this connection has not been shown in human intervention studies. Because breast cancer is one of the most common cancer diseases, there is still a need from a basal point of view to learn more about the occurrence and functions of selenoproteins in mammary tissue.

Also, a number of Se-deficiency symptoms are known in farm animals. Selenium deficiency in cows can lead to retained placenta and abortion, and in calves to white muscle disease, a degenerative disease of heart and skeletal muscle, which can be fatal (Koller and Exon, 1986). Several studies have shown that supplementing the feed with Se and vitamin $\mathrm{E}$ can reduce both the severity and the duration of mastitis in cows and also the somatic cell count in milk (Hemingway, 1999). Selenium supplementation of cow feed can result in increased concentration of Se both in blood and milk (Ortman and Pehrson, 1999), which can be beneficial to 
both suckling calves and to humans because milk and other dairy products are important sources of Se in the diet (Becker, 2000). One selenoprotein, the extracellular GPx 3, has been demonstrated in both human and bovine milk using immunochemical methods (Avissar et al., 1991; Lindmark-Månsson and Åkesson, 2001). The occurrence of other selenoproteins in milk and their effects on dairy consumers and possible influence on technical properties of dairy products has not been established.

The secretion of proteins into milk is a complex process because some of them are formed in mammary tissue and others originate from blood plasma (McManaman and Neville, 2003). In addition to their possible roles as precursors of milk Se compounds, different mammary selenoproteins may have a regulatory role in other physiological processes in the mammary gland such as inflammation and redox processes (Cao et al., 2000). In the mouse mammary gland, the mStaf factor (mouse selenocysteine transfer RNA gene transcription-activating factor) has been found to stimulate the transcription of the tRNA ${ }^{\text {Sec }}$ and its activity peaks during lactation and can be induced by lactogenic hormones (Adachi et al., 1999), which indicates that lactation may affect the selenoproteins in mammary tissue and milk.

The formation of selenoproteins in the mammary gland and their secretion into milk has not been extensively studied. For such studies it is necessary to know the occurrence and activity of different selenoproteins in mammary tissue. Therefore, we measured the expression and activities of some selenoproteins and also Se concentration in bovine mammary tissue to study the variation between randomly selected cows and the correlations between different variables.

\section{MATERIALS AND METHODS}

\section{Chemicals}

For the enzyme assays, reduced glutathione, mercaptosuccinate, BSA, 5, $5^{\prime}$-dithio-bis (2-nitrobenzoic acid) (DTNB), and NADPH were obtained from Sigma Chemical Co. (St. Louis, MO). Tert-butylhydroperoxide and EDTA were purchased from Merck (Darmstadt, Germany), and glutathione reductase (EC 1.6.4.2) from Boehringer Mannheim (Mannheim, Germany). Aurothioglucose was purchased from Research Diagnostics, Inc. (Flanders, NJ) and 99.5\% spectrography-grade ethanol from Kemetyl (Haninge, Sweden). Ultrapure water (resistivity: $18 \mathrm{M} \Omega \mathrm{cm}$ ) was produced using a Milli-Q water purification system (Millipore, Bedford, MA). For the mRNA measurements, albumin (fraction V) was obtained from Merck. Ultrapure SDS and Tris were obtained from ICN Biomedicals (Irvine, CA). Electrophoresis-grade agarose was manufactured by In- vitrogen (Carlsbad, CA) and molecular biology-grade 3-morpholinopropanesulfonic acid (MOPS) was from Research Organics (Cleveland, OH). Other chemicals were of analytical grade.

\section{Mammary Tissue}

Bovine mammary tissue from 9 cows was obtained at a local slaughterhouse immediately after slaughter and was transported to the laboratory without delay. Most of the cows were between 5 and $10 \mathrm{yr}$ old, were multiparous, and were Swedish Friesian or Swedish Red and White cattle. Information on the lactation stages and composition of diets the cows had consumed was not available. Tissue for the analysis of enzyme activity and soluble Se was taken from 4 different parts of the udder and transported on ice. One sample of tissue for mRNA analysis was transported on dry ice. Samples of bovine liver and kidney for mRNA analysis were also collected. All samples were frozen at $-80^{\circ} \mathrm{C}$ until tissue preparation and analysis.

\section{Preparation of Tissue for Enzyme Analysis}

Four samples were collected at the same time from different parts of each udder. The tissue samples were thawed by immersion of the tubes in water at room temperature. Five grams of tissue was mixed with 20 $\mathrm{mL}$ of cold potassium phosphate buffer $(80 \mathrm{mM}, \mathrm{pH} 7.6)$ containing $5 \mathrm{~m} M$ EDTA and homogenized in a rotating blade mixer (MSE, Crawley, UK) for $5 \mathrm{~min}$. The homogenate was filtered through a filter cloth (Sefar Nitex 03-200/54 Sefar AG, Heiden, Germany) and then centrifuged for $60 \mathrm{~min}$ at $50,000 \times \mathrm{g}$ and $4^{\circ} \mathrm{C}$. The layer of fat on the surface was removed, and then the supernatant was again filtered through filter cloth. The supernatant was stored at $-80^{\circ} \mathrm{C}$ for later analysis.

\section{Assay of GPx Activity}

The assay of GPx activity was adapted from a previously described method (Chen et al., 2000). Sample was added to a cuvette containing $0.63 \mathrm{~m} M$ glutathione, $5 \mu \mathrm{g} / \mathrm{mL}$ glutathione reductase, $0.25 \mathrm{~m} M \mathrm{NADPH}, 5$ $\mathrm{m} M$ EDTA, and $50 \mathrm{~m} M$ phosphate buffer ( $\mathrm{pH}$ 7.6). After incubation of the mixture at $37^{\circ} \mathrm{C}$ for $4 \mathrm{~min}, 0.1 \mathrm{mM}$ tert-butylhydroperoxide was added to initiate the reaction. The absorbance was measured at $340 \mathrm{~nm}$ for 2 min (Ultrospec 3000, Amersham Biosciences, Uppsala, Sweden). Mercaptosuccinate ( $4 \mathrm{mM})$ was used to specifically inhibit the GPx activity in the sample blank. The assay temperature was $37^{\circ} \mathrm{C}$ and the total volume of the reaction mixture was $0.8 \mathrm{~mL}$. Two measurements were made on each sample and the average activity in 
each part of the udder was calculated. These 4 values were in turn used to calculate the average value for the udder for statistical calculations. One enzyme activity unit (U) was defined as one micromole of NADPH oxidized per minute.

\section{Assay of Thioredoxin Reductase Activity}

The analysis was based on the direct reduction of DTNB by thioredoxin reductase (TrxR) and the susceptibility of the enzyme to inhibition by gold (Hill et al., 1997b). The mammary supernatant was thawed and filtered through a $0.45-\mu \mathrm{m}$ filter (Millipore), and then added to a cuvette containing $0.1 \mathrm{~m} M$ potassium phosphate buffer (pH 7.0), $5 \mathrm{~m} M$ DTNB, $10 \mathrm{~m} M$ Na-EDTA, and $0.2 \mathrm{~g} / \mathrm{L}$ of BSA equilibrated at $37^{\circ} \mathrm{C}$ for $3 \mathrm{~min}$. The absorbance at $412 \mathrm{~nm}$ was measured every minute for $24 \mathrm{~min}$, and $5 \mu \mathrm{L}$ of NADPH $(40 \mathrm{mM})$ was added after $5 \mathrm{~min}$. The assay was carried out at $37^{\circ} \mathrm{C}$ and the total volume in the cuvette was $1 \mathrm{~mL}$. In the sample blank, $5 \mu \mathrm{L}$ of gold thioglucose $(4 \mathrm{mM}) \mathrm{kept}$ at $37^{\circ} \mathrm{C}$ was added to inhibit thioredoxin reductase. One enzyme activity unit (U) was defined as one micromole of DTNB reduced per minute. Duplicate measurements were made and the average activity for each part of the udder was calculated. These 4 values were in turn used to calculate the average value for the udder for statistical calculations.

\section{Analysis of Se and Protein}

The Se concentration was measured by an inductively coupled plasma-mass spectrometer (Thermo X7, Thermo Elemental, Winsford, UK) equipped with a conical glass nebulizer (Glass Expansion, Melbourne, Australia) with $1 \mathrm{~mL} / \mathrm{min}$ uptake and a peltier-chilled conical impact bead spray chamber. The gas flows were 13 $\mathrm{L} / \mathrm{min}$ for the cooling gas, $1.1 \mathrm{~L} / \mathrm{min}$ for the auxiliary gas, and $0.93 \mathrm{~mL} / \mathrm{min}$ for nebulizer gas. The samples were analyzed in peak-jumping mode for ${ }^{79} \mathrm{Br},{ }^{77} \mathrm{Se}$, and ${ }^{82} \mathrm{Se}$ (3 points per peak, $30 \mathrm{~ms}$ dwell time) in timeresolved analysis mode. The data for ${ }^{79} \mathrm{Br}$ were used to correct for the content of the hydride of ${ }^{81} \mathrm{Br}$ in the $\mathrm{m} / \mathrm{z} 82$ peak. Soluble protein was measured according to Lowry et al. (1951).

\section{Preparation of Tissue for mRNA Analysis}

Frozen tissue samples were either transitioned in RNAlater ICE (Ambion Inc., Austin, TX) to stabilize the RNA before homogenization or homogenized immediately while still frozen. The RNA extraction was performed using the RNeasy Lipid Tissue Midi Kit (Qiagen GmbH, Hilden, Germany) according to the manufactur- er's instructions. The tissue was homogenized for 30 to 60 s using an Ultra Turrax TP 18/10 homogenizer (Janke and Kunkel, Ika-werk, Staufen, Germany). Total RNA was eluted from the columns in $150 \mu \mathrm{L}$ of RNase-free water and stored at $-80^{\circ} \mathrm{C}$.

\section{Construction of mRNA Probes}

Probes were constructed to detect the mRNA by Northern blot for selenoprotein P (SeP), TrxR 1, GPx 1,3 , and 4 , and $\beta$-actin using reverse transcriptionPCR (Titan One Tube RT-PCR Kit, Roche Diagnostics GmbH, Mannheim, Germany) using total RNA or polyA+ RNA isolated from bovine liver or kidney as template. Purification of total RNA was performed using Trizol reagent (Invitrogen) according to the manufacturer's instructions with the exception that the precipitation was performed at $-20^{\circ} \mathrm{C}$ overnight, instead of at room temperature for $10 \mathrm{~min}$. To obtain poly A+ RNA from the total RNA, the Oligotex mRNA mini kit (Qiagen) was used. Additional aliquots of the probes were produced by PCR of the original probes using Taq DNA polymerase, buffer, and nucleotide mix from Fermentas (Helsingborg, Sweden). After PCR, the primers and PCR buffer were removed using a Microspin S-400 column (Amersham Biosciences) according to the manufacturer's general protocol A. Primer sequences, annealing temperatures, and probe sizes are shown in Table 1.

The probe for $\beta$-actin was constructed using the sequence for a $\beta$-actin pseudogene, which was the only sequence available at the time, but a BLAST comparison showed that both primer sequences matched the real sequence in 20 out of 21 nucleotides. The produced probe was sequenced and found to match the real sequence and not the pseudogene, which is probably not expressed (Davey and Wildeman, 1995).

\section{Northern Blot}

The RNA concentration was determined by spectrophotometry at $260 \mathrm{~nm}$ in a Beckman Coulter DU 640 spectrophotometer (Fullerton, CA), and approximately $10 \mu \mathrm{g}$ of total RNA was separated by electrophoresis on a $1.0 \%$ agarose gel equilibrated with $220 \mathrm{mM}$ formaldehyde, $20 \mathrm{~m} M$ MOPS, $5 \mathrm{~m} M$ sodium acetate, and 1 $\mathrm{m} M$ EDTA. To visualize the RNA, ethidium bromide was added to the gel. Loading buffer and electrophoresis buffer were made according to the protocol recommended in the RNeasy Mini Handbook (Qiagen). The gel was blotted onto a Hybond-N filter (Amersham Biosciences) with $20 \times$ saline sodium citrate (SSC; $1 \times$ $\mathrm{SSC}=150 \mathrm{~m} M \mathrm{NaCl}$ and $50 \mathrm{~m} M$ sodium citrate, $\mathrm{pH}$ 7.0) by capillary transfer. The RNA was bound to the 
Table 1. Primer sequences and annealing temperatures used to produce probes for Northern blot ${ }^{1}$

\begin{tabular}{|c|c|c|c|c|}
\hline Probe & Sense primer & Antisense primer & $\begin{array}{l}\text { Size } \\
\text { (bp) }\end{array}$ & $\begin{array}{c}\text { Temp. } \\
\left({ }^{\circ} \mathrm{C}\right)\end{array}$ \\
\hline GPx $1^{2}$ & 5'-CGC GCA CAG TGT ACG CCT TC-3' & 5'-CTG GGA CAG CAG GGT TTC AAT-3' & 557 & 58 \\
\hline GPx 3 & 5'-GAA CTG AAT GCA CTG CAG GA-3' & 5'-CTC AAA GTT CCA CCG GAT GT-3' & 312 & 60 \\
\hline $\mathrm{SeP}^{3}$ & 5'-CTT CAT CAC CAC CAC CAC AG-3' & 5'-GAG GCA AAC GTC ACT GTC AA-3' & 331 & 60 \\
\hline $\operatorname{TrxR} 1^{4}$ & 5'-AAT GTG GGT TGC ATA CCT AA-3' & 5'-TAG AGA GAA AAG ATC ATC AC-3' & 378 & 55 \\
\hline$\beta$-actin & $5^{\prime}$-AAC CGT GAG AAG ATG ACT CAG- $3^{\prime}$ & $5^{\prime}$-GGC CAT TTC CTG CTC GAA GTC-3' & 342 & 60 \\
\hline
\end{tabular}

${ }^{1}$ The whole mRNA sequences are from NCBI Entrez Nucleotide (http://www.ncbi.nlm.nih.gov/entrez/query.fcgi?db=Nucleotide\&itool= toolbar).

${ }^{2} \mathrm{GPx}=$ glutathione peroxidase.

${ }^{3} \mathrm{SeP}=$ selenoprotein $\mathrm{P}$.

${ }^{4}$ TrxR 1 = thioredoxin reductase 1; Hara et al., 2001.

membrane using a CL-1000 Ultraviolet Crosslinker (UVP Inc., Upland, CA). The membrane was then washed in $2 \times \mathrm{SSC}$, dried, and stored at $8^{\circ} \mathrm{C}$. To assess the transfer of RNA to the membrane, the membrane was first immersed in $0.9 \mathrm{M}$ acetic acid for $10 \mathrm{~min}$ and then in a dye solution containing $1.3 \mathrm{~m} M$ methylene blue in $0.5 \mathrm{M}$ sodium acetate buffer, $\mathrm{pH} 5.2$ for $2 \mathrm{~min}$. The membrane was washed in MilliQ-water, photographed, and then washed in $2 \times \mathrm{SSC}$ and dried or hybridized.

Three RNA preparations were made from each bovine mammary tissue sample, and 3 membranes were made from each preparation, resulting in 9 membranes containing 1 sample from each animal. Each membrane also contained RNA samples of bovine liver and kidney as positive controls. Each membrane was hybridized 1 or 2 times with selenoprotein probes resulting in 3 hybridizations for every probe, each on membranes from separate preparations. At last, all membranes were hybridized with the probe for $\beta$-actin, a housekeeping gene, to be used as normalization for loading differences between the samples. One membrane containing only mRNA was made by extracting mRNA from $40 \mu \mathrm{g}$ of total RNA using the Oligotex mRNA mini kit (Qiagen) and loading the resulting mRNA on a $0.95 \%$ agarose gel.

\section{Hybridization}

The DNA probes were labeled with ${ }^{32} \mathrm{P}$ using the Rediprime Random prime labeling system (Amersham Biosciences) according to the manufacturer's instructions using the option of letting the labeling reaction proceed overnight at room temperature or at 30 to 60 min at $37^{\circ} \mathrm{C}$ instead of at $10 \mathrm{~min}$ at $37^{\circ} \mathrm{C}$. The labeled probe was then purified by eliminating unbound ${ }^{32} \mathrm{P}$ using a Microspin S-200 column (Amersham Biosciences). The radioactivity of the purified probe was measured using a $\beta$-counter.
The hybridization was performed in a Robbins Scientific hybridization incubator, model 400 (Sunnyvale, $\mathrm{CA})$ at $65^{\circ} \mathrm{C}$. The membrane was first prehybridized for at least $15 \mathrm{~min}$ in $10 \mathrm{~mL}$ of hybridization solution $(0.5$ $M$ sodium phosphate buffer, $\mathrm{pH}$ 6.8, $1 \mathrm{mM}$ EDTA, 0.24 $M$ SDS, $10 \mathrm{~g} / \mathrm{L}$ of BSA). This solution was then discarded and new hybridization solution containing labeled probe $\left(10^{6} \mathrm{cpm} / \mathrm{mL}\right)$ was added, and the hybridization was performed overnight. The next day the hybridization solution was removed, and the membrane was washed at $65^{\circ} \mathrm{C}$ with $2 \times \mathrm{SSC}, 3.5 \mathrm{~m} M$ SDS for $20 \mathrm{~min}$; $1 \times \mathrm{SSC}, 3.5 \mathrm{~m} M$ SDS for $20 \mathrm{~min}$; and $0.1 \times \mathrm{SSC}, 3.5$ $\mathrm{m} M$ SDS twice for $20 \mathrm{~min}$. The membrane was evaluated with a Geiger-Müller tube to ascertain the level of background radiation. The membrane was then washed further if needed or put in a plastic envelope and placed against a storage phosphor plate (Fujifilm, Tokyo, Japan), which was read using a Fujifilm FLA 3000 fluorescent image analyzer after an appropriate time, usually 1 to $4 \mathrm{~d}$. The resulting images were analyzed using Image Gauge V4.0, and the results were normalized against the level of the housekeeping gene ( $\beta$-actin) to compensate for loading differences. Deprobing of membranes between hybridizations was done by pouring boiling $3.5 \mathrm{~m} M$ SDS on the membranes and letting it cool. The membranes were washed and the deprobing assessed with a Geiger-Müller tube. The procedure was repeated if necessary.

The hybridization showed that some samples that seemed undegraded after the electrophoresis (i.e., the ribosomal RNA was intact) were actually somewhat degraded. For this reason, data from sample $\mathrm{E}$ and one of the preparations of sample $\mathrm{G}$ were excluded from the evaluation of the mRNA measurements.

\section{Statistical Calculations}

All statistical calculations were performed using the SPSS 13.0 software (SPSS Inc., Chicago, IL). The 
Kruskal-Wallis $\mathrm{H}$ and Mann-Whitney $U$-test nonparametric methods were used to determine differences among animals for the enzyme activity and the soluble Se measurements. Correlations between these variables were calculated using Pearson's method. Also, $95 \%$ confidence intervals were calculated on the basis of the $t$ distribution.

Because the ratios produced after the normalization of the expression of selenoproteins relative to $\beta$-actin could not be compared between membranes due to differences in labeling and exposure time, 2 approaches were used to evaluate the results of the Northern labeling. For every enzyme, each sample was given a rank within each membrane, and the data from the $3 \mathrm{mem}$ branes were compared using the Kruskal-Wallis $\mathrm{H}$ test, grouped after animal. If this test showed that there was statistical difference in expression among the animals, the Mann-Whitney $U$-test was used to assess the differences among the individual animals. The second approach was to normalize the data from each membrane by dividing the ratios obtained after $\beta$-actin normalization with the ratio of the kidney sample that was run on each membrane. The kidney RNA used came from one single preparation and should therefore produce similar results on the different membranes. The membranes hybridized with GPx 3 could not be normalized against the kidney sample because of the extremely strong signal of GPx 3; they were normalized against the sample with the lowest signal on each membrane (animal C). These data were used to calculate 95\% confidence intervals according to the $t$ distribution for the enzymes that were found to have statistical differences among animals according to ANOVA, complemented with the Welch and Brown-Forsythe tests to compensate for differences in variance.

Correlations between the mean enzyme activities, mean soluble Se, mean normalized ratios of expression, and median rank of expression of enzymes for each animal were calculated using Spearman's rho.

\section{RESULTS}

\section{Soluble Se and Selenoprotein Enzyme Activity}

The activity of GPx in the mammary supernatants varied approximately 16 -fold, and TxrR activity and the concentration of soluble Se varied about 6-fold among different cows (Table 2). For all variables, the same cow (animal H) had the lowest value. Statistically significant positive correlations were found between all 3 variables (Table 2), the correlation between GPx activity and soluble Se being the strongest (Figure 1). The activity of GPx and TrxR and the levels of soluble Se for each animal, including 95\% confidence intervals, are shown in Figure 2.
The Kruskal-Wallis test showed that there were differences among animals in all of these 3 variables. The individual differences between pairs of animals were calculated by the Mann-Whitney $U$-test (Table 3 ). Seven subsets were found in the comparison between animals for the GPx activity and 4 and 5 subsets were found for TrxR activity and soluble Se concentration, respectively.

\section{mRNA Measurements}

For all 5 selenoproteins assayed, mRNA was detected (Figure 3). All probes gave good signals except for the TrxR 1 probe that only gave a weak signal on the membranes made using total RNA. When the TrxR 1 probe was hybridized to a membrane containing only mRNA, clear signals were detected. In the positive controls, a particularly strong signal was produced by hybridization of the GPx 3 probe in kidney and of the SeP probe in liver.

There was a marked similarity in the ranks and in the normalized ratios of each animal between the 3 hybridizations for the GPx 3 probe (Figure 4). Good reproducibility was seen for the GPx 1 probe and also to some degree for $\mathrm{SeP}$, but for the other probes there was a larger scatter in data among membranes. The Kruskal-Wallis test applied on the rank data showed statistical differences among the animals for the expressions of GPx 1 and GPx 3 but not for SeP, GPx 4, and TrxR 1. The Mann-Whitney $U$-test showed that there were statistical differences between several of the animals, particularly regarding the expression of GPx 3 (Table 3). Using the normalized ratios of expression, significant differences were found among animals in GPx 1, GPx 3, and SeP according to ANOVA, and the approximate fold changes among animals were 3 to 4 for GPx 1, 7 for GPx 3, and 2 for SeP. Mean values and $95 \%$ confidence intervals of these data are shown in Figure 5.

\section{Associations Among Variables}

When comparing the different variables using either the mean or the median values for each animal, a positive correlation between GPx activity and GPx 1 mRNA expression was found (Figure 6). Furthermore, SeP expression correlated with GPx 1 expression and with soluble Se. A negative correlation between the expressions of GPx 3 and GPx 4 was also seen (Table 4). Tendencies toward a correlation could also be observed between some variables, e.g., soluble Se vs. expression of GPx 1 and GPx activity and also between the expressions of GPx 1 and GPx 3. 
Table 2. Descriptive statistics and correlations regarding glutathione peroxidase (GPx) activity, thioredoxin reductase (TrxR) activity, and soluble Se content in bovine mammary tissue supernatant ${ }^{1}$

\begin{tabular}{|c|c|c|c|c|c|c|}
\hline & Mean & $\mathrm{SD}$ & Minimum & Maximum & $\begin{array}{c}\text { Fold } \\
\text { difference }\end{array}$ & $\mathrm{n}$ \\
\hline GPx activity (U/g of protein) & 32.7 & 20.0 & 3.8 & 62.1 & 16 & 9 \\
\hline GPx activity (U/g of tissue) & 1.59 & 1.01 & 0.24 & 3.69 & 16 & 9 \\
\hline TrxR activity (U/g of protein) & 1.54 & 0.62 & 0.43 & 2.41 & 6 & 9 \\
\hline TrxR activity (U/g of tissue) & 0.085 & 0.050 & 0.028 & 0.169 & 6 & 9 \\
\hline Soluble Se ( $\mu \mathrm{g} / \mathrm{g}$ of protein) & 1.05 & 0.42 & 0.28 & 1.56 & 6 & 9 \\
\hline \multirow[t]{2}{*}{ Soluble Se (ng/g of tissue) } & 56.2 & 30.2 & 18.3 & 92.5 & 5 & 9 \\
\hline & & & & & $\mathrm{r}$ & $P$ \\
\hline \multicolumn{5}{|c|}{ Soluble Se ( $\mu \mathrm{g} / \mathrm{g}$ of protein) vs. GPx activity (U/g of protein) } & 0.77 & $<0.001$ \\
\hline \multicolumn{5}{|c|}{ Soluble Se ( $\mu \mathrm{g} / \mathrm{g}$ protein) vs. TrxR activity (U/g of protein) } & 0.39 & 0.019 \\
\hline \multicolumn{5}{|c|}{ GPx activity (U/g protein) vs. TrxR activity (U/g of protein) } & 0.45 & 0.006 \\
\hline
\end{tabular}

${ }^{1}$ The descriptive statistics are based on the average value for each animal. The correlations were calculated according to Pearson's method and are based on measurements of 4 different samples per animal $(\mathrm{n}=36)$.

\section{DISCUSSION}

\section{Enzyme Activity and Soluble Se}

No study has previously demonstrated glutathione peroxidase and thioredoxin reductase activities in bovine mammary tissue. The occurrence of these activities is in accordance with ${ }^{75}$ Se labeling data obtained in mouse mammary gland (Kumaraswamy et al., 2003). In the present study, it was shown that the concentration of soluble Se and the activity of TrxR and GPx varied among cows and that there were significant positive correlations between these 3 variables. This indicates that Se status is an important factor for the activity of these selenoproteins in bovine mammary tissue,

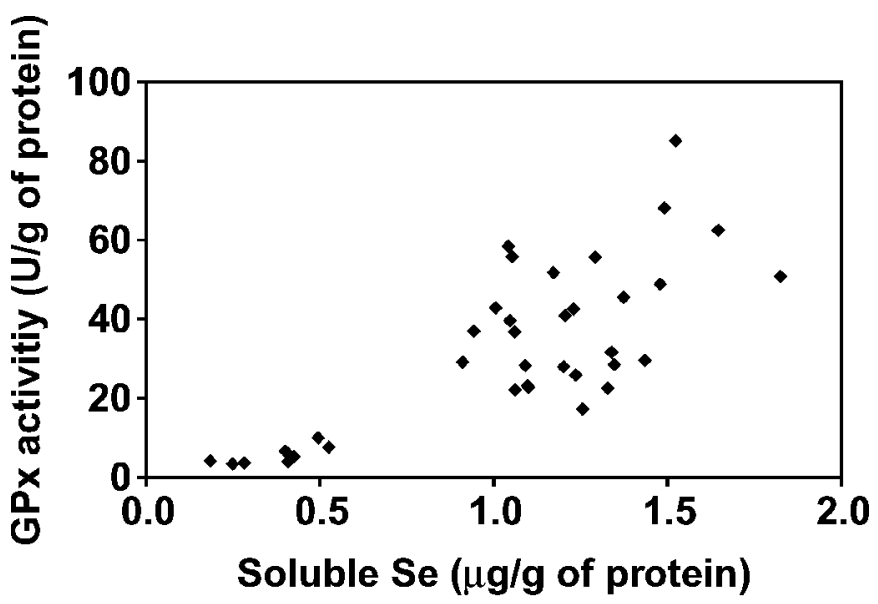

Figure 1. Scatter plot of glutathione peroxidase (GPx) activity (units/g of protein) vs. soluble Se ( $\mu \mathrm{g} / \mathrm{g}$ of protein) in bovine mammary tissue supernatant. Four data points per animal are shown $(\mathrm{r}=0.77$; $P<0.001$ according to Pearson's method). particularly for GPx. Several studies on the effect of Se supply on selenoproteins have shown that the activity of both TrxR and GPx were decreased in Se-deficient rats (Hill et al., 1997a; Hadley and Sunde, 2001), which is in agreement with the present data. Those studies also demonstrated that GPx activity is one of the most sensitive variables responding to Se deficiency, which was also reflected in the different fold changes in enzyme activity in our study (Table 2). In other studies, however, inverse relationships have been demonstrated between TrxR and GPx activities (Gladyshev et al., 1998; Wu et al., 2003). Wu et al. (2003) found in rat aorta that whereas GPx expression and activity decreased in Se-deficient rats, both the expression and

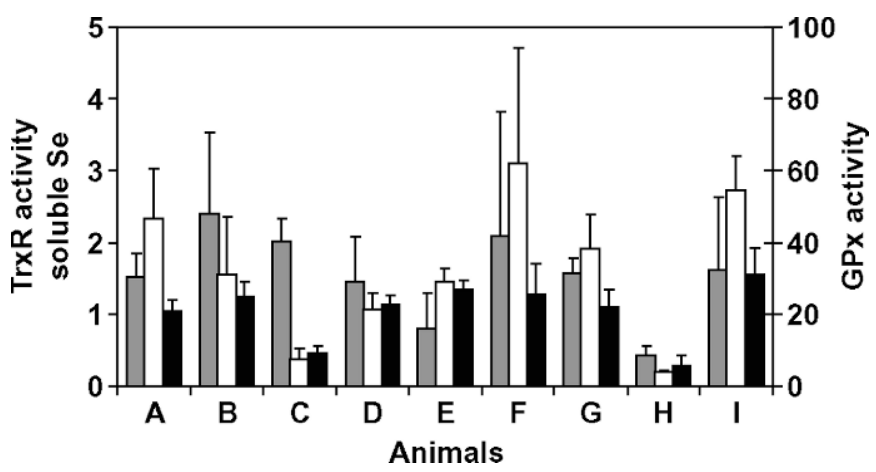

Figure 2. Mean activity of thioredoxin reductase (TrxR, gray bar, units/g of protein), glutathione peroxidase (GPx, white bar, units/g of protein), and soluble Se (Sol Se, black bar, $\mu \mathrm{g} / \mathrm{g}$ of protein) in the supernatant of mammary tissue from individual cows. Calculations were made using the mean value for 4 samples of each udder. Error bars represent the positive part of the $95 \%$ confidence interval based on the $t$ distribution. The GPx activity is denoted on the right vertical axis. 
Table 3. Statistically significant differences between animals in selenoprotein variables as assessed according to the Mann-Whitney $U$-test ${ }^{1}$

\begin{tabular}{|c|c|c|c|c|c|c|c|c|}
\hline A & $\underset{H}{\text { Animal }}$ & $\begin{array}{l}1 \\
\mathrm{H}\end{array}$ & 2 & 3 & 4 & 5 & 6 & 7 \\
\hline & $\begin{array}{l}\mathrm{H} \\
\mathrm{C}\end{array}$ & H & $\overline{\mathrm{C}}$ & - & - & - & 二 & - \\
\hline & $\mathrm{D}$ & - & - & $\mathrm{D}$ & - & - & - & - \\
\hline & B & - & - & B & B & B & - & - \\
\hline & $\mathrm{E}$ & - & - & - & $\mathrm{E}$ & - & - & - \\
\hline & G & - & - & - & G & G & G & - \\
\hline & $\mathrm{A}$ & - & - & - & - & A & A & $\mathrm{A}$ \\
\hline & I & - & - & - & - & - & $\bar{\Gamma}$ & I \\
\hline & $\mathrm{F}$ & - & - & - & - & - & F & $\mathrm{F}$ \\
\hline B & Animal & 1 & 2 & 3 & 4 & & & \\
\hline & $\mathrm{H}$ & $\mathrm{H}$ & $\bar{T}$ & - & - & & & \\
\hline & $\mathrm{E}$ & - & $\mathrm{E}$ & $\bar{D}$ & - & & & \\
\hline & D & - & - & D & - & & & \\
\hline & A & - & - & A & - & & & \\
\hline & G & - & - & G & - & & & \\
\hline & I & - & - & I & I & & & \\
\hline & $\mathrm{F}$ & - & $\mathrm{F}$ & $\mathrm{F}$ & $\mathrm{F}$ & & & \\
\hline & C & - & - & - & C & & & \\
\hline & B & - & & - & B & & & \\
\hline C & Animal & 1 & 2 & 3 & 4 & 5 & & \\
\hline & C & $\mathrm{C}$ & - & - & - & - & & \\
\hline & $\mathrm{H}$ & - & $\mathrm{H}$ & - & - & - & & \\
\hline & F & - & - & $\mathrm{F}$ & - & - & & \\
\hline & D & - & - & D & - & - & & \\
\hline & B & - & - & - & B & - & & \\
\hline & A & - & - & - & - & A & & \\
\hline & I & - & 二 & $\bar{G}$ & - & I & & \\
\hline & G & - & - & u & - & G & & \\
\hline D & Animal & 1 & 2 & 3 & & & & \\
\hline & $\mathrm{H}$ & $\mathrm{H}$ & $\bar{a}$ & - & & & & \\
\hline & C & $\mathrm{C}$ & $\mathrm{C}$ & - & & & & \\
\hline & D & D & D & D & & & & \\
\hline & $\mathrm{A}$ & A & $\mathrm{A}$ & A & & & & \\
\hline & I & - & I & - & & & & \\
\hline & B & - & B & B & & & & \\
\hline & $\mathrm{F}$ & - & - & $\mathrm{F}$ & & & & \\
\hline & G & G & G & G & & & & \\
\hline $\mathrm{E}$ & Animal & 1 & 2 & 3 & 4 & 5 & & \\
\hline & $\mathrm{H}$ & $\mathrm{H}$ & $\bar{a}$ & - & - & - & & \\
\hline & C & - & C & - & - & - & & \\
\hline & A & - & - & A & - & - & & \\
\hline & $\mathrm{G}$ & - & - & G & G & - & & \\
\hline & D & - & - & D & D & $\overline{-}$ & & \\
\hline & $\mathrm{F}$ & - & - & $\mathrm{F}$ & $\mathrm{F}$ & $\mathrm{F}$ & & \\
\hline & B & - & - & - & B & B & & \\
\hline & $\mathrm{E}$ & - & - & - & - & $\mathrm{E}$ & & \\
\hline & I & - & - & - & - & I & & \\
\hline
\end{tabular}

${ }^{1}$ Animals located in the same subset (columns) did not differ significantly from each other $(P>0.05)$. The order of the animals was determined by the mean rank order according to the Kruskal-Wallis H procedure. Panel A: glutathione peroxidase activity; B: thioredoxin reductase activity; C: mRNA expression of glutathione peroxidase 3; D: mRNA expression of glutathione peroxidase 1; E: soluble Se.

activity of TrxR increased and appeared to be regulated by the level of reactive oxygen species rather than the Se supply.

\section{mRNA Measurements}

In the mRNA measurements, a very strong signal of GPx 3 and a strong signal of SeP were detected in kidney and liver, respectively, which is consistent with previous findings and also confirmed the affinity of these probes for the correct target RNA (Avissar et al., 1994; Burk and Hill, 2005). The differences seen for the TrxR 1 probe between total RNA and mRNA membranes might be due to difficulties in transfer of the large TrxR 1 transcript from the gel and the fact that the position of this transcript coincided with that of the 


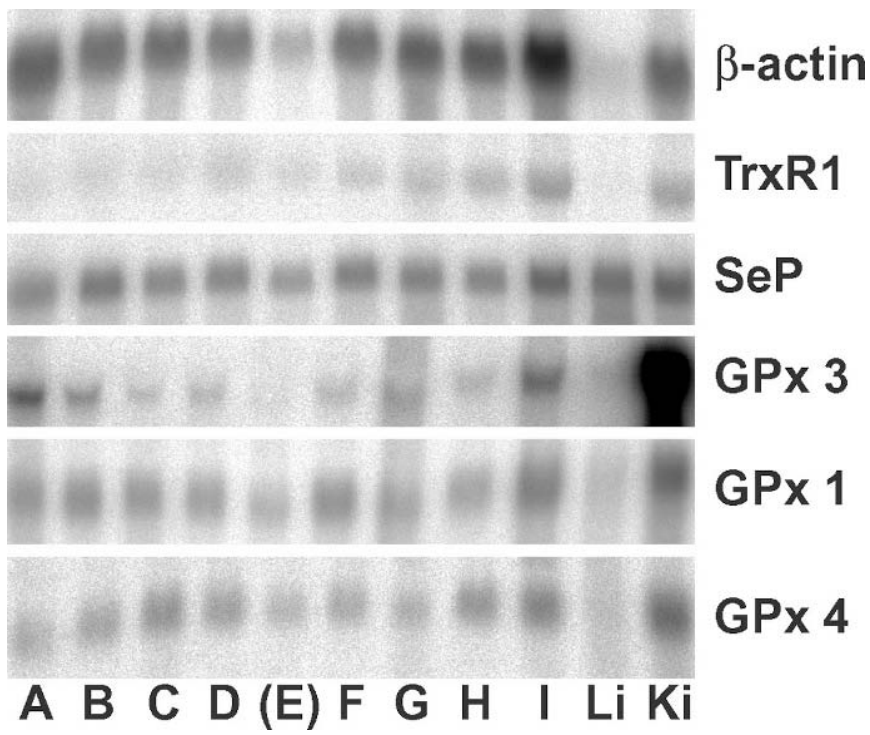

Figure 3. Autoradiogram images for 5 selenoprotein probes in bovine mammary tissue. $\mathrm{A}$ to $\mathrm{I}=$ different animals; $\mathrm{Li}=$ liver; $\mathrm{Ki}=$ kidney; $\operatorname{TrxR} 1$ = thioredoxin reductase $1 ; \mathrm{SeP}=$ selenoprotein $\mathrm{P}$; $\mathrm{GPx}=$ glutathione peroxidase .

28S rRNA, leading to interference with probe hybridization.

In the mRNA experiments, a statistically significant difference among animals was shown for GPx 1 and 3 in the comparison using ranks and for GPx 1 and 3 and $\mathrm{SeP}$ in the comparison using normalized ratios. No differences were seen for GPx 4 or TrxR 1 . These results are consistent with the results of prior studies on other tissues from other animals where a major decrease in GPx 1 and 3 mRNA and GPx activity has been found in Se-deficient samples with no or minor changes in mRNA levels of SeP, GPx 4, and TrxR 1. Selenium

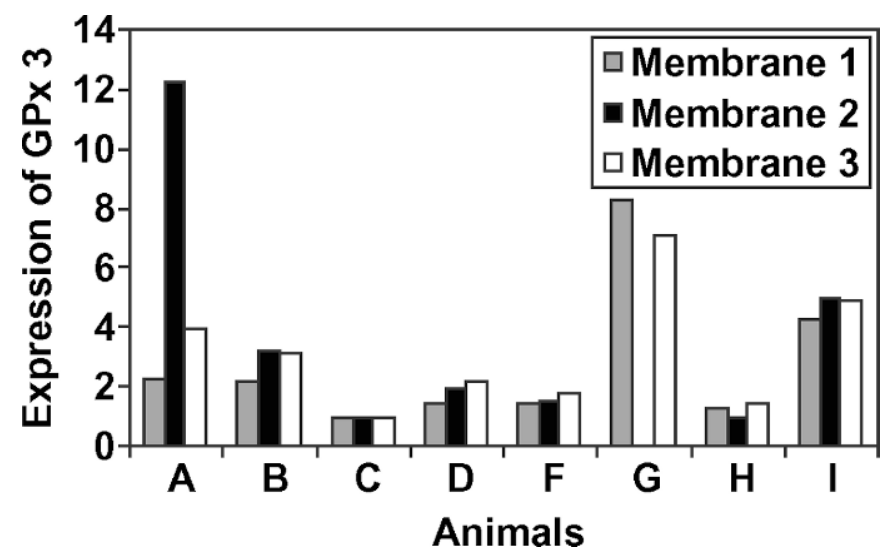

Figure 4. Expression of glutathione peroxidase 3 (GPx 3) in bovine mammary gland normalized against the expression in animal C. Each series represents one membrane. deficiency may, however, result in a marked decrease in TrxR activity, even if its mRNA level changes very little (Nakane et al., 1998; Hadley and Sunde, 2001; Hara et al., 2001).

\section{Correlations Among Variables}

In the comparisons between individual animals, different patterns were seen for the individual variables studied showing that Se supply is not the only factor influencing selenoprotein activity and expression. Still, for most variables, 2 animals $(\mathrm{C}, \mathrm{H})$ had very low values, indicating that these cows had a lower Se status than the other ones, as shown by the low concentration of soluble Se. This is illustrated clearly in Figure 1, where the 8 data points forming a small cluster at the low end of the scales represent the measurements of animal $\mathrm{H}$ and $\mathrm{C}$.

The positive correlation between GPx activity and GPx 1 mRNA level was expected because in most tissues, GPx 1 is the major form of glutathione peroxidase (Behne and Kyriakopoulos, 2001). Regarding the correlations among soluble Se, mRNA expression of SeP and GPx 1 and 3, and GPx activity, it is likely that all these variables basically correlate to the Se concentration available in the tissue, but the 8 or 9 data points available were not always sufficient to reach statistical significance. This was obvious when comparing the correlations between the means and those obtained using 4 measurements per animal for soluble Se and TrxR and GPx activity (Table 2). The GPx 4 expression rather followed the opposite trend as the variables mentioned above, since it correlated inversely with the GPx 3 expression, indicating that GPx 4 expression in bovine

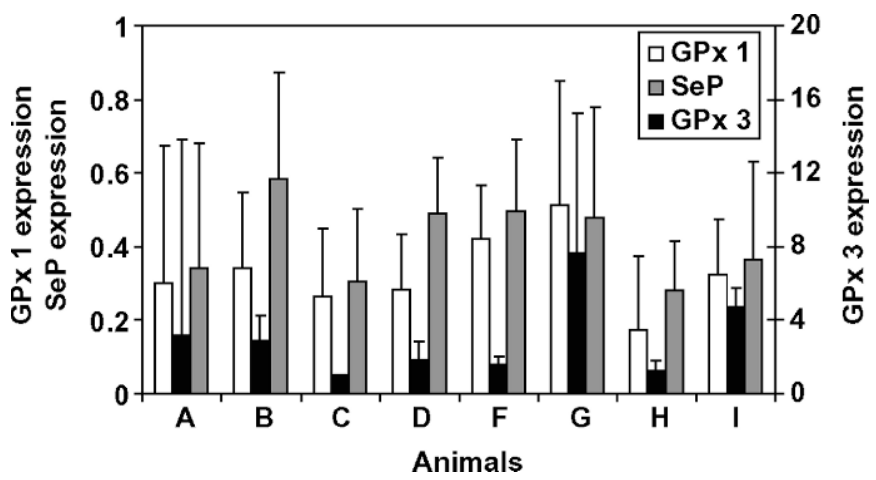

Figure 5. Mean ratios of glutathione peroxidase 1 (GPx 1) and selenoprotein $\mathrm{P}(\mathrm{SeP})$ expression normalized to a kidney sample (left axis) and the expression of glutathione peroxidase 3 (GPx 3 ) normalized against the lowest sample (C; right axis) in bovine mammary tissue. One value from each membrane was used in calculations except for animals $\mathrm{A}$ and $\mathrm{G}$, where values from one membrane were excluded due to outliers. Error bars represent the positive part of the $95 \%$ confidence interval according to the $t$ distribution. 
Table 4. Significant correlations found between variables of selenoprotein gene expression and enzyme activity in bovine mammary tissue ${ }^{1}$

\begin{tabular}{lcc}
\hline & $\mathrm{r}$ & $P$ \\
\hline Mean GPx ${ }^{2}$ activity (U/g) vs. median GPx 1 rank & 0.75 & 0.033 \\
Mean GPx activity (U/g) vs. mean normalized GPx 1 expression & 0.74 & 0.037 \\
Mean normalized SeP ${ }^{3}$ expression vs. median GPx 1 rank & 0.71 & 0.048 \\
Mean normalized SeP expression vs. mean normalized GPx 1 expression & 0.71 & 0.047 \\
Median GPx 4 rank vs. median GPx 3 rank & -0.79 & 0.02 \\
Median GPx 4 rank vs. mean normalized GPx 3 expression & -0.79 & 0.02 \\
Mean normalized SeP expression vs. mean soluble Se & 0.74 & 0.037 \\
\hline
\end{tabular}

\footnotetext{
${ }^{1}$ Means or medians were used to calculate Spearmans' rho $(n=8$ to 9$)$. The average value for each animal
} was used in the calculations.

${ }^{2} \mathrm{GPx}=$ Glutathione peroxidase.

${ }^{3} \mathrm{SeP}=$ Selenoprotein $\mathrm{P}$.

mammary tissue is less affected by Se deficiency than the other 2 glutathione peroxidases. The TrxR 1 expression did not correlate with any of the other variables, possibly indicating that it was not affected by Se status in bovine mammary tissue, which is consistent with other studies (Hadley and Sunde, 2001; Hara et al., 2001).

An additional aim of the present study was to perform a feasibility study aiming at the application of measurements of different Se-related variables in bovine mammary tissue. An interesting question for future studies will be to investigate whether selenoprotein expression and activity in the bovine mammary gland besides Se status are affected by additional variables such as lactation stage, lactation number, age of the cow, and feed composition.

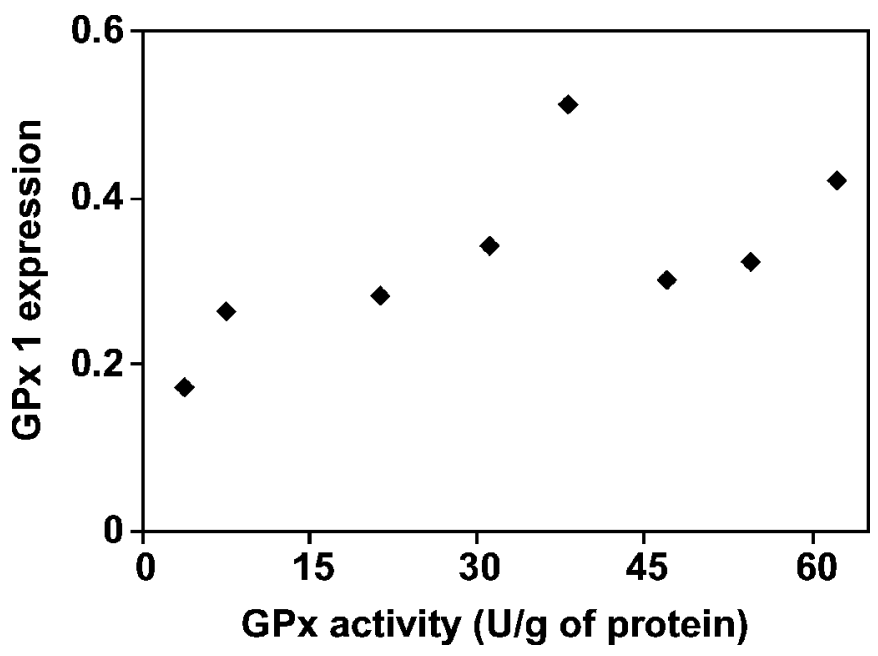

Figure 6. Association of glutathione peroxidase (GPx) activity in bovine mammary tissue to glutathione peroxidase 1 (GPx 1) expression as normalized to a kidney sample. Each data point represents the mean value for each cow $(\mathrm{r}=0.74 ; P=0.037$ according to Spearman's method).

\section{ACKNOWLEDGMENTS}

The study was supported by the Swedish Research Council for Environment, Agricultural Sciences and Spatial Planning, the Swedish Farmer's Foundation for Agricultural Research, Öforsk (the Committee for Research and Development of the Öresund Region), the Faculty of Engineering LTH, Lund University, the Påhlsson Foundation, the J. Andersson Foundation, the Swedish Dairy Association and Lund University Hospital. We thank Thomas Lundh for performing the Se analyses, Annette Säfholm for construction of the mRNA probes, Karolina Andersson for advice on mRNA analysis, Anna Igerud and Karin Schläwicke for help with the enzyme assays, and Helena Lindmark-Månsson for background data on cows and for helpful advice. Biomedical Nutrition is a member of the EU NoE The European Nutrigenomics Organisation (NuGO, no. 505944) and the NoE Environmental Cancer Risk, Nutrition and Individual Susceptibility (ECNIS, no. 513943), which partly supported the study.

\section{REFERENCES}

Adachi, K., T. Tanaka, H. Saito, and T. Oka. 1999. Hormonal induction of mouse selenocysteine transfer ribonucleic acid (tRNA) gene transcription-activating factor and its functional importance in the selenocysteine tRNA gene transcription in mouse mammary gland. Endocrinology 140:618-623.

Avissar, N., D. B. Ornt, Y. Yagil, S. Horowitz, R. H. Watkins, E. A. Kerl, K. Takahashi, I. S. Palmer, and H. J. Cohen. 1994. Human kidney proximal tubules are the main source of plasma glutathione peroxidase. Am. J. Physiol. 266:367-375.

Avissar, N., J. R. Slemmon, I. S. Palmer, and H. J. Cohen. 1991. Partial sequence of human plasma glutathione peroxidase and immunologic identification of milk glutathione peroxidase as the plasma enzyme. J. Nutr. 121:1243-1249.

Beck, M. A., O. A. Levander, and J. Handy. 2003. Selenium deficiency and viral infection. J. Nutr. 133:1463-1467.

Becker, W. 2000. Vilka är källorna till våra näringsämnen? Vår Föda. $3: 16-20$.

Behne, D., H. Hilmert, S. Scheid, H. Gessner, and W. Elger. 1988. Evidence for specific selenium target tissues and new biologically important selenoproteins. Biochim. Biophys. Acta 966:12-21. 
Behne, D., and A. Kyriakopoulos. 2001. Mammalian selenium-containing proteins. Annu. Rev. Nutr. 21:453-473.

Burk, R. F., and K. E. Hill. 2005. Selenoprotein P: An extracellular protein with unique physical characteristics and a role in selenium homeostasis. Annu. Rev. Nutr. 25:215-235.

Cao, Y. Z., C. C. Reddy, and L. M. Sordillo. 2000. Altered eicosanoid biosynthesis in selenium-deficient endothelial cells. Free Radic. Biol. Med. 28:381-389.

Chen, J., H. Lindmark Månsson, and B. Åkesson. 2000. Optimisation of a coupled enzymatic assay of glutathione peroxidase activity in bovine milk and whey. Int. Dairy J. 10:347-351.

Davey, H. W., and A. G. Wildeman. 1995. Molecular analysis of bovine actin gene and pseudogene sequences: Expression of nonmuscle and striated muscle isoforms in adult tissues. DNA Cell Biol. 14:555-563.

Gladyshev, V. N., V. M. Factor, F. Housseau, and D. L. Hatfield. 1998. Contrasting patterns of regulation of the antioxidant selenoproteins, thioredoxin reductase, and glutathione peroxidase, in cancer cells. Biochem. Biophys. Res. Commun. 251:488-493.

Hadley, K. B., and R. A. Sunde. 2001. Selenium regulation of thioredoxin reductase activity and mRNA levels in rat liver. J. Nutr. Biochem. 12:693-702.

Hara, S., Y. Shoji, A. Sakurai, K. Yuasa, S. Himeno, and N. Imura. 2001. Effects of selenium deficiency on expression of selenoproteins in bovine arterial endothelial cells. Biol. Pharm. Bull. 24:754-759.

Hemingway, R. G. 1999. The influences of dietary selenium and vitamin $\mathrm{E}$ intakes on milk somatic cell counts and mastitis in cows. Vet. Res. Commun. 23:481-499.

Hill, K. E., G. W. McCollum, M. E. Boeglin, and R. F. Burk. 1997a. Thioredoxin reductase activity is decreased by selenium deficiency. Biochem. Biophys. Res. Commun. 234:293-295.

Hill, K. E., G. W. McCollum, and R. F. Burk. 1997b. Determination of thioredoxin reductase activity in rat liver supernatant. Anal. Biochem. 253:123-125.

Ip, C., D. J. Lisk, and H. J. Thompson. 1996. Selenium-enriched garlic inhibits the early stage but not the late stage of mammary carcinogenesis. Carcinogenesis 17:1979-1982.

Koller, L. D., and J. H. Exon. 1986. The two faces of seleniumdeficiency and toxicity-are similar in animals and man. Can. J. Vet. Res. 50:297-306.
Kryukov, G. V., S. Castellano, S. V. Novoselov, A. V. Lobanov, O. Zehtab, R. Guigo, and V. N. Gladyshev. 2003. Characterization of mammalian selenoproteomes. Science 300:1439-1443.

Kumaraswamy, E., B. A. Carlson, F. Morgan, K. Miyoshi, G. W. Robinson, D. Su, S. Wang, E. Southon, L. Tessarollo, B. J. Lee, V. N. Gladyshev, L. Hennighausen, and D. L. Hatfield. 2003. Selective removal of the selenocysteine tRNA [Ser] Sec gene (Trsp) in mouse mammary epithelium. Mol. Cell. Biol. 23:1477-1488.

Lindmark-Månsson, H., and B. Akesson. 2001. Purification and immunochemical assay of bovine extracellular glutathione peroxidase. Int. Dairy J. 11:649-655.

Lowry, O. H., N. J. Rosebrough, A. L. Farr, and R. J. Randall. 1951. Protein measurement with the Folin phenol reagent. J. Biol. Chem. 193:265-275.

McManaman, J. L., and M. C. Neville. 2003. Mammary physiology and milk secretion. Adv. Drug Deliv. Rev. 55:629-641.

Müller, C., K. Wingler, and R. Brigelius-Flohé. 2003. 3'UTRs of glutathione peroxidases differentially affect selenium-dependent mRNA stability and selenocysteine incorporation efficiency. Biol. Chem. 384:11-18.

Nakane, T., K. Asayama, K. Kodera, H. Hayashibe, N. Uchida, and S. Nakazawa. 1998. Effect of selenium deficiency on cellular and extracellular glutathione peroxidases: Immunochemical detection and mRNA analysis in rat kidney and serum. Free Radic. Biol. Med. 25:504-511.

Ortman, K., and B. Pehrson. 1999. Effect of selenate as a feed supplement to dairy cows in comparison to selenite and selenium yeast. J. Anim. Sci. 77:3365-3370.

Rayman, M. P. 2000. The importance of selenium to human health. Lancet 356:233-241.

Schweizer, U., and L. Schomburg. 2005. New insights into the physiological actions of selenoproteins from genetically modified mice. IUBMB Life 57:737-744.

Unni, E., F. S. Kittrell, U. Singh, and R. Sinha. 2004. Osteopontin is a potential target gene in mouse mammary cancer chemoprevention by Se-methylselenocysteine. Breast Cancer Res. 6:586592.

Wu, Q., K. Huang, and H. Xu. 2003. Effects of long-term selenium deficiency on glutathione peroxidase and thioredoxin reductase activities and expressions in rat aorta. J. Inorg. Biochem. 94:301-306. 